\title{
Małgorzata Kamecka
}

Uniwersytet w Białymstoku

\section{Miejsca i ludzie w fotografii. Paryż Eugène'a Atgeta}

\begin{abstract}
Malarstwo może udawać realność nie widząc jej [...]. W przeciwieństwie do tych imitacji, w przypadku Fotografii nigdy nie mogę zanegować faktu, że ta rzecz tam była. Jest podwójna płaszczyzna: realności i przeszłości.
\end{abstract}

Roland Barthes ${ }^{1}$

Od początku swego istnienia - czyli od lat czterdziestych XIX wieku - fotografia rejestruje życie miasta i zachodzące w nim zmiany. Już pierwsze dagerotypowe panoramy przynoszą wiele informacji o ówczesnej miejskiej strukturze przestrzennej. Ich autorzy uważnie śledzą wszelkie przejawy działalności człowieka, dokumentując sceny z życia codziennego i ludzi przy pracy ${ }^{2}$.

\section{Związki fotografii z życiem miasta}

Nie można więc rozpatrywać natury i funkcji fotografii $\mathrm{w}$ oderwaniu od przemian dokonujących się $\mathrm{w}$ miastach. Nowoczesność fotografii oraz uprawomocnienie jej dokumentalnego charakteru oparte są bowiem na ścisłych relacjach, jakie łączą się z najbardziej typowymi cechami społeczeństwa przemysłowego: rozwój metropolii, procesy demokratyzacyjne, rozwój

1 R. Barthes, Światto obrazu. Uwagi o fotografii, przeł. J. Trznadel, Warszawa 1996, s. 130.

2 P. Sztompka, Socjologia wizualna. Fotografia jako metoda badawcza, Warszawa 2006, s. 25. 
gospodarki opartej na pieniądzu, a nade wszystko przeobrażenia $\mathrm{w}$ przestrzeni i związane $\mathrm{z}$ nimi zmiany w czasie komunikacji. Pisząc o związkach fotografii z miastem, André Rouillé zauważa: „Miejsca, daty, zastosowane techniki, fakty: wszystko zdaje się potwierdzać, że wynalezienie fotografii idealnie wpisuje się $\mathrm{w}$ dynamikę tworzącego się społeczeństwa przemysłowego" ${ }^{3}$. Miała ona być narzędziem służącym ekspresji społeczeństwa przemysłowego, dostosowanym do jego rytmu i poziomu techniki. Już w połowie XIX wieku fotografia stanowiła najlepszą odpowiedź na wszystkie te oczekiwania i potrzeby ${ }^{4}$. Znalazła się tym samym w sercu nowoczesności i pełniła rolę dokumentu. Ten status pozwolił jej uwierzytelnić i legitymizować to wszystko, co przedstawiała, gdyż potrafiła najskuteczniej i najtrafniej dokumentować dokonujące się zmiany ${ }^{5}$.

Nowym obszarem zainteresowania dziewiętnastowiecznych artystów fotografików stała się przestrzeń publiczna, ulica. Jej wygląd i rozgrywający się na niej spektakl przyciąga ich, stając się niewyczerpanym źródłem inspiracji. „Fotografia - zauważa Susan Sontag - dochodzi do głosu jako przedłużenie dla oka flâneura baudelairowskiego" ${ }^{\prime}$. Z powstających w tym czasie zdjęć emanuje bowiem podobna przyjemność przyglądania się i podglądania. W miarę postępowania urbanizacji dokumentaliści otwarcie fotografowali ludzi, ich różnorodność, charakter slumsów czy dzielnic robotniczych? Wielu fotografów interesujących się pejzażem miejskim dokonywało prób uchwycenia nieprzerwanego biegu życia, szczególnego zbadania i zasmakowania miejskiej atmosfery. $\mathrm{Z}$ wielkim upodobaniem oddawał się uwiecznianiu paryskich miejsc - placów targowych, parków, imprez - m.in. Hippolyte Jouvin (1825-1887).

Innym aspektem fotografii społecznej w owym czasie było poszukiwanie niespodziewanych wydarzeń, towarzyszących nudnemu, codziennemu życiu. Fotografia chce uchwycić czas, w obliczu zanikania cech charakterystycznych kultury danych społeczeństw, w których zaczynała dominować ustandaryzowana moda na ubiór i zachowanie ${ }^{8}$.

3 A. Rouillé, Fotografia: między dokumentem a sztukq wspótczesna, przeł. O. Hedernann, Kraków 2007, s. 22.

4 Tamże, s. 23.

5 Tamże, s. 22. Życiem miejskim interesowali się również artyści malarze. O wpływie fotografii na rozwój tej dziedziny sztuki świadczy wyraźnie charakter twórczości impresjonistów. Zerwali oni z tradycją, preferując przypadkowy układ postaci, z których kilka jest przeciętych, niemieszczących się $w$ ramach obrazu, tak jak to się zdarzało na płycie fotograficznej. Przykładem tych działań jest dzieło Claude'a Moneta Bulwar des Capucines (1873-1874).

6 S. Sontag, O fotografii, przeł. S. Magala, Warszawa 1986, s. 56.

7 N. Rosenblum, Historia fotografii światowej, przeł. I. Baturo, Bielsko-Biała 2005, s. 262.

8 Tamże, s. 264. Jacques Henri Lartigue (1894-1986) wychwytywał tego rodzaju niespo- 
W czasach, kiedy miasta przeżywają swój rozkwit i głębokie przemiany o charakterze społecznym, demograficznym i architektonicznym, wynikające również z dynamizacji życia codziennego w kulturze społeczeństw Europy Zachodniej, fotografie mają za zadanie uchwycić czas i zatrzymać dawny pejzaż, utracony bezpowrotnie pod naporem modernizacji. Jak widać na przykładzie dziewiętnastowiecznego Paryża, wraz z nowym urbanistycznym układem metropolii tworzą się nowe miejsca i przestrzenie, pojawiają się w nich nowi ludzie. Aparat fotograficzny okazuje się więc sprzymierzeńcem $\mathrm{w}$ procesie rejestracji i dokumentacji narodzin nowej stolicy i schyłku dawnej. W tej sytuacji powstające zdjęcia stają się nieocenionym świadectwem ścierania się i konfrontacji "nowego" ze "starym”.

W niniejszym studium pragnę przywołać postać Eugène'a Atgeta, „piewcy Paryża”, ,"Balzaka fotografii”, ,dokumentalisty ginących miejsc”, jak określali go krytycy. Zwłaszcza to ostatnie określenie skłania do odczytywania jego twórczości przede wszystkim jako zapisu procesu przemijania. Tym bardziej więc warto zastanowić się nad kształtowaniem się relacji między fotografem - wrażliwym obserwatorem i świadkiem odchodzącego świata a różnymi miejscami w Paryżu i związanymi z nimi ludzi. Godny uwagi jest także stosunek Atgeta do fotografowanych przez niego obiektów.

Wybrane przeze mnie aspekty jego twórczości - nierozerwalnie związane $z$ historią stolicy Francji - muszą być wpisane w kontekst problemów związanych $\mathrm{z}$ realizacją planu zmiany oblicza miasta. Ta zaś przypadła na drugą połowę XIX wieku.

\section{Georges Haussmann - „minister” Paryża (1853-1870)}

Gruntowna modernizacja stolicy Francji rodzi się z uporu, ambicji i konsekwencji Napoleona III. Powierza on gigantyczne zadanie przebudowy, zakrojone na wiele lat, prefektowi departamentu Seine, baronowi Haussmannowi. To dzięki ich staraniom Paryż, z dwoma milionami mieszkańców, osiąga status największej aglomeracji na kontynencie, stając się niekwestionowaną europejską stolicą „wielkiego świata" 9 .

dzianki. Ze zdjęcia pt. Avenue des Bois de Boulogne bije obojętność i chłód zamożnych Europejczyków tuż przed pierwszą wojną światową. Głównymi motywami stają się więc ekstremalne kontrasty, malowniczość miasta i wprost voyeurystyczna ciekowość.

9 L'Histoire de Paris par la peinture, sous la direction de G. Douby, avec la collaboration de G. Lobrichon, Belfond, 1988, s. 270; J. Kowalski, A. i M. Loba, J. Prokop, Dzieje kultury francuskiej, Warszawa 2005, s. 441. 
W pierwszym rzędzie, stopniowej poprawie ulega ogólny stan sanitarny miasta. Istotną rolę pełni tu rozbudowywana sieć wodociągów ${ }^{10}$. Do paryskich mieszkań podłącza się kanalizację i gaz. Z centrum znikają zaniedbane kompleksy budynków, na ich miejscu pojawiają się eleganckie, haussmannowskie kamienice. Nowe budowle, takie jak Opera Garnier czy kościół Saint-Augustin, nadają stolicy dodatkowy splendor. Przez centrum miasta przebija się szerokie arterie komunikacyjne, gdzie asfalt wypiera dotychczasowy bruk, zaś oświetlenie gazowe - olej. Całości podejmowanych działań niewątpliwie przyświeca troska o modernizację i komfort życia mieszkańców i przyjezdnych, ale nie tylko. Kryje się za nimi konkretny i przemyślany plan polityczny Drugiego Cesarstwa: zaprowadzić nowy ład i sprawnie rozprawić się z opozycją. Rządzący mają pełną świadomość zagrożeń wynikających z ulicznych zgromadzeń. Przecież na wąskich uliczkach łatwiej wznieść barykady, wykorzystać bruk do walki z siłami porządkowymi i schronić się anonimowo $\mathrm{w}$ ciemności pod ledwie tlącymi się latarniami ${ }^{11}$. Natomiast eleganckie, szerokie ulice nie sprzyjają zbuntowanym uczestnikom zgromadzeń. Nowoczesny układ urbanistyczny Paryża odzwierciedla więc ambicje - polityczne, ekonomiczne i kulturalne - ówczesnej władzy, harmonię i porządek nowych czasów.

Obrazowaniu przeszłości miasta w czasach jego modernizacji poświęcił swe życie Eugène Atget, autor niezwykłej dokumentacji Paryża, niedościgły mistrz uwieczniania miejsc skazanych na zniszczenie, zapomnienie i niebyt.

\section{Eugène Atget - dokumentalista ginących miejsc}

Jak kształtowała się życiowa droga tego skromnego fotografa, który ze swego rzemiosła uczynił prawdziwą sztukę? Urodził się w 1857 roku w Libourne, niedaleko Bordeaux. Wcześnie stracił rodziców i po ukończeniu szkoły pracował jako chłopiec okrętowy i marynarz. W latach osiemdziesiątych grywał $\mathrm{w}$ prowincjonalnych teatrzykach, realizując swe marzenie o byciu aktorem. Sceniczną pasję próbował kontynuować w Paryżu, do którego przeprowadził się na stałe w 1890 roku. Po kilku latach, gdy stało się jasne, że nie uda mu się zrobić kariery $\mathrm{w}$ metropolii, zainteresował się sztukami wizualnymi, wybierając fotografię. Mimo braku wykształcenia w dziedzinie sztuki sądził, że zawód fotografa przyniesie mu dobry

\footnotetext{
10 G. Le Gall, Architecture et monuments, http://expositions.bnf.fr/atget/arret/04.htm [dostęp 14.12.2013].

11 L'Histoire de Paris, s. 274.
} 
zysk ze sprzedaży zdjęć sąsiadom - artystom z paryskiej dzielnicy Montparnasse $^{12}$. W latach 1898-1914 sprzedał wiele zdjęć robionych na zlecenie różnych urzędów miasta, w tym zdjęcia dla archiwum narodowego pomników oraz nowo otwartego muzeum Carnavalet, instytucji powołanej do życia z myślą o zbieraniu informacji na temat Paryża ${ }^{13}$. Z czasem, oprócz wykonywania zdjęć na konkretne zamówienie, artysta zaczyna podążać za indywidualnymi zainteresowaniami. Naznaczał je własnym oryginalnym spojrzeniem, co zyskało mu miano „Rousseau fotografii”. Tak jak Charles Marville (1813-1879) fotografował przedmieścia Paryża i dlatego można uznać go za kontynuatora tradycji fotografów lat pięćdziesiątych XIX wieku, którzy uczestniczyli w projekcie „Monuments historiques”. W 1921 roku planowano wydanie książki ze zdjęciami domów publicznych, ale do tej realizacji nigdy nie doszło. Ostatni rok życia artysty zalicza się do najtrudniejszych, nie tylko zmarła jego wieloletnia przyjaciółka, ale i dodatkowo dręczyły go problemy finansowe.

Pierwsze wystawy dorobku artysty, zmarłego w 1927 roku, miały miejsce rok po jego śmierci. W latach dwudziestych zakres tematyczny prac Atgeta i ich wartość artystyczną znało tylko niewielkie grono przyjaciół i artystów awangardowych ${ }^{14}$, wśród nich Berenice Abbott, wielbicielka stylu fotografa, późniejsza właścicielka całej kolekcji zdjęć, odbitek, albumów i negatywów, zakupionych już po śmierci ich autora. Po powrocie do Nowego Jorku Abbott udało się zainteresować spuścizną Atgeta amerykańskich kolekcjonerów, zaś w 1968 roku odsprzedała ją w całości Museum of Modern Art. Zasług Abbott w propagowaniu twórczości artysty, a zwłaszcza traktowania jego prac jako dzieł sztuki (przed czym zresztą sam fotograf wzbraniał się za życia) nie sposób przecenić. François Soulages tak oto wypowiada się na temat zmiany, jaka dokonała się w sposobie odczytywania fotografii Atgeta:

By przemyśleć kwestię przeniesienia z bez-sztuki do sztuki, powinniśmy rozważyć dzieło Eugène'a Atgeta oraz zaskakujący sposób jego wykorzystania, upowszechnienia oraz odczytania, których dokonała Berenice Abbott. Wyzyskała ona nieskończoność do tego stopnia, że paradoksalnie stworzyła zakończenie dzieła Atgeta, być może niemożliwego do ukończenia: fotografia Atgeta została definitywnie przeniesiona $\mathrm{z}$ bez-sztuki do sztuki ${ }^{15}$.

12 B. von Brauchitsch, Mała historia fotografii, przeł. J. Koźbiał, B. Tarnas, Warszawa 2004, s. 239.

13 N. Rosenblum, Historia fotografii światowej, s. 279.

14 Zaliczał się do nich m.in. Man Ray (1890-1976). Jego asystentką była właśnie Berenice Abbott (1898-1991). Artysta przyczynił się do opublikowania kilku zdjęć Atgeta w Révolution surréaliste, mimo iż sam autor fotografii prosił, aby nie podpisywano zdjęć jego nazwiskiem.

15 F. Soulages, Estetyka fotografii. Strata i zysk, przeł. B. Mytych-Forajter, W. Forajter, Kraków 2007, s. 180. 
Niespożyta energia, systematyczność i pracowitość to cechy wyróżniające artystę, który w obliczu urbanistycznych i społecznych przemian pragnął utrwalić ślad obrazujący „resztki Paryża jako małego miasteczka, ustępującego pod naporem metropolii" ${ }^{16}$. Pozostawił po sobie gigantyczną spuściznę ocenianą na około 10 tysięcy zdjęć. Tę, zdaniem krytyków, największą, a dla niektórych najbardziej ekspresyjną dokumentację życia Paryża rozpoczął Atget w roku 1900. Jako zapalony czytelnik francuskiej literatury dziewiętnastowiecznej usiłował odtworzyć Paryż z przeszłości, fotografując budynki przeznaczone do rozbiórki i tereny, które miały zniknąć. Prostym aparatem $(18 \times 24)$ ustawionym na statywie, zaczął wykonywać zdjęcia miast z myślą o szerokim gronie odbiorców: architektach, projektantach, malarzach, wydawcach i rzeźbiarzach ${ }^{17}$. Prowadził przy tym dokładny rejestr fotografowanych miejsc, jak też nazwisk sponsorów.

Fotografie artysty stanowią swoisty hołd złożony „temu, co było, a czego już nie ma" i do dzisiaj nie mają sobie równych w procesie przywoływania pamięci o nieistniejących już zakątkach stolicy i jej dawnych mieszkańcach. Atget wyznawał pogląd, że dokumentacja i sztuka wzajemnie się nie wykluczają, dlatego też fotografował każdy, nawet banalny temat ${ }^{18}$. Pięknie skomponowane zdjęcia prezentują oczywistą wartość, nie tylko ze względu na dokumentalny zapis budowli, pomników, strojów i ogrodów ${ }^{19}$, lecz również witryn sklepowych, wykonanych około 1910 roku. Te ostatnie przyniosły Atgetowi szczególne uznanie krytyków sztuki. Ten aspekt jego twórczości wyjątkowo upodobała sobie Susan Sontag, poświęcając mu uwagę w swych rozważaniach o fotografii ${ }^{20}$. Odbicia, które dotychczas pomagały fotografom $w$ komponowaniu zdjęć przedstawiających wnętrza i pejzaże, teraz służyły jako środek badania twórczych możliwości stwarzanych przez tworzywa o powierzchniach załamujących światło, na przykład tafle grubego szkła lub wypolerowanego metalu. W zdjęciach Atgeta naturalne i geometryczne formy odbijające się w oknach często wywołują marzycielską atmosferę. W opublikowanej w 1930 roku przez Waltera Benjamina monografii poświęconej pracom Atgeta pojawia się opinia: „Paryskie zdjęcia Atgeta były dziełami prekursorskimi fotografii surrealistycznej, awangardą falangi, jaką

16 S. Sontag, O fotografii, s. 68.

17 A. Rouillé, Fotografia: między dokumentem a sztuką wspótczesną, s. 22.

18 Twórca nie wykazywał jednak specjalnego zainteresowania fotografią artystyczną, przecież rozwijającej się w tym okresie.

19 N. Rosenblum, Historia fotografii światowej, s. 272.

20 S. Sontag, O fotografii, s. 188. 
wprawił w ruch” ${ }^{21}$. O stapianiu się „nadrealności” z realnością w spuściźnie fotograficznej Atgeta pisze też Urszula Czartoryska, podając za przykład wykonane przez niego zdjęcie manekina $\mathrm{z}$ wystawy sklepowej:

Breton potrafił w zdjęciach Atgeta przeczuć - witrynach sklepów z odzieżą czy zakładów fryzjerskich, w manekinach, kramach handlarzy koszy, żelastwa, w szyldach - magiczną, urzekającą moc przedmiotu. Przedmiot taki natrafia niejako w pamięci widza na wizje podobnych przedmiotów, będące wspomnieniem własnych przeżyć, przeżyć doznanych zarówno na jawie, jak i we śnie ${ }^{22}$.

Artysta tworzył w przekonaniu, że dzięki swym pracom zachowa dla potomnych świadectwa czasu i sposobów wykorzystania w architekturze kamienia, żelaza i roślinności. Seria zdjęć przedstawiających drzewa w parku została przez niego wykonana w okolicach Paryża (La Marne à la Varenne) ${ }^{23}$. Ponieważ już wówczas odczuwano skutki uprzemysłowienia w północnych dzielnicach miasta, można te zdjęcia odczytać jako wyraz ogromnego pragnienia twórcy, by zachowało się środowisko naturalne. Odnosząc się do tego aspektu twórczości Atgeta, Urszula Czartoryska przywołuje opinię Michaela Starenko - autora studiów z zakresu socjologii fotografii - według którego często mylnie odczytuje się spuściznę artysty ,jako rezultat «osobliwego» włóczęgowskiego zamiłowania wędrownego fotografa, który z uporem powracał wciąż do tych samych miejsc" ${ }^{24}$. Według cytowanego przez badaczkę krytyka, Atget w swojej twórczości bardzo świadomie wyrażał tęsknotę za przeszłością, co czyni go wnikliwym dokumentalistą „upływającego czasu, rozsypującego nieubłaganie ruiny i kruszącego stare zaułki" 25. Idąc za tym porównaniem, Starenko dostrzega więc w nim raczej cechy „polemisty nowej ideologii burżuazyjnego "postępu»" 26 , który sprzeciwia się industrializacji, degradującej wiejski charakter okolic stolicy.

Atgeta - twierdzi Czartoryska - należy rozumieć jako ideologa nostalgii (to słowo dziś modne), oddając mu szacunek jako krytycznemu obserwatorowi dewastacji i piewcy poczucia ciągłości w obyczaju i krajobrazie ${ }^{27}$.

\footnotetext{
21 B. von Brauchitsch, Mała historia fotografii, s. 122.

22 U. Czartoryska, Fotografia - mowa ludzka. Perspektywy historyczne, red. L. Brogowski, Gdańsk 2006, s. 147.

23 Zdjęcia ukazują Wersal, Sceaux, Saint-Cloud.

24 U. Czartoryska, Fotografia - mowa ludzka. Perspektywy teoretyczne, s. 197.

25 Tamże.

26 Tamże.

27 Tamże.
} 


\section{Dwa miasta w fotografii Eugène'a Atgeta}

Gdy ogląda się fotografie Atgeta, zwłaszcza te, na których pojawiają się ludzie, odnosi się nieodparte wrażenie, że artysty nie interesuje życie społecznej i finansowej elity, jej przedstawicieli przechadzających się po nowych bulwarach ${ }^{28}$. Ten Paryż nie jest wart jego uwagi. Stąd też konsekwentnie i świadomie stroni on od fotografowania nowych wielobranżowych magazynów („grands magasins") czy innych miejsc "zbiorowej konsumpcji” 29. Bardziej odpowiadają mu inne miejsca, usytuowane niejako na tyłach głównych miejskich arterii, a swą sympatią obdarza również tych, których życie i praca toczy się z dala od prężnie rozwijającego się centrum ${ }^{30}$. Fotografie stają się tym samym wartościowym świadectwem życia poza centrum miasta, nabierają charakteru społecznego reportażu ukazującego kondycję jednostek przesuniętych na peryferie miejskiej przestrzeni i odbywających się tam wydarzeń. Wybór artysty czyni z handlarzy szmatami oraz ludzi z marginesu aktorów pierwszego planu i nadaje przynależną im godność. To oni, nierozerwalnie złączeni z miejscem swego istnienia i działalności, tworzą tkankę miejską. Przebywając na przedmieściach zmieniają ich charakter, czyniąc z obszarów pozornie opuszczonych enklawy przetrwania, a nawet swoistego rozwoju ${ }^{31}$. Napełniają je swą obecnością i witalnością. Nie można zatem sprowadzić twórczości Atgeta jedynie do nostalgicznego zapisu odchodzącego świata. Z fotografii, ukazujących mały handel uliczny czy życie na przedmieściach, przebija bowiem dynamika i siła drugiego życia metropolii. Pozornie skazany na zniszczenie "stary" Paryż, nie tylko żyje i trwa wraz ze swą wewnętrzną organizacją, tradycjami i zwyczajami, ale wręcz stanowi prawdziwą alternatywę dla modernizacji i zmian zainicjowanych przez Haussmanna. Wobec tego utożsamiać z miastem należałoby, według Atgeta, wszystkich tych, którzy ożywiają jego ulicę i kształtują przestrzeń, a więc drobnych sklepikarzy czy ulicznych handlarzy: wszak to oni zamieszkują "stary" Paryż. Trafnie ujmuje tę dwoistość w postrzeganiu francuskiej metropolii Guillaume Le Gall, znawca twórczości artysty, pisząc:

\footnotetext{
28 G. Le Gall, La rue, http://expositions.bnf.fr/atget/arret/06.htm [dostęp 14.12.2013].

29 M. Dymnicka, Od miejsca do nie-miejsca, "Acta Universitatis Lodzensis. Folia Sociologica” 2011 , t. 36 , s. 44 .

30 Artysta rozwinie tematykę poświęconą mieszkańcom przedmieść w albumie zatytułowanym Les Zoniers: G. Le Gall, Les habitants, http://expositions.bnf.fr/atget/arret/07.htm [dostęp 14.12.2013].

31 A. Mons, Les lieux du sensible. Villes, homes, images, Paris 2013, s. 57-67. Autor rozważa na tych stronach sposób przedstawiania peryferii miast $\mathrm{w}$ fotografii.
} 
Dla Atgeta istniały "dwa miasta” w jednym i tym samym mieście. Dlatego, można wyróżnić w nim dwa teatry i dwie miejskie scenerie [...]. Atget buduje scenerię swego miejskiego teatru, fotografując puste ulice starego Paryża. Fotografowani przez niego paryżanie uchwyceni są w swym bezpośrednim środowisku, tworzonym przez miejską tkankę ${ }^{32}$.

Tak więc znaczenie określenia "stary” w odniesieniu do Paryża nie powinno ograniczać się do funkcji nazywania tego, co nowe $\mathrm{w}$ historii miasta, nie powinno być kategorią wymyśloną i używaną przez miłośników przeszłości. Należałoby raczej posługiwać się nim w odniesieniu do głównych skutków procesów modernizacyjnych prowadzonych przez Haussmanna. $W$ ich wyniku bowiem uwidoczniła się stara tkanka miejska świadcząca o śladach dawnego miasta. Najwyraźniej świadomość istnienia tej tkanki towarzyszy Atgetowi w pracy, żmudnym dziele dokumentacji i przywrócenia pamięci, również o ludziach związanych z tymi "starymi” przestrzeniami.

Utrwalonym obrazem swego Paryża artysta potwierdza, że nie ogranicza się jedynie do zapisu i opisu miasta-artefaktu. Wyraźnie widać, że opowiada się on po stronie jego mieszkańców, zepchniętych na margines przez procesy urbanizacyjne. Cyklem zdjęć, w których portretuje ubogą ludność zamieszkującą tereny usytuowane pomiędzy fortyfikacjami i przedmieściami (banlieue) zwraca uwagę na istnienie biednych dzielnic (zone). W tamtym okresie stanowiły one własność wojska, teren non aedificandi, i jako takie nie nadawały się pod stałą zabudowę. Pojawienie się tam ludności w zasadniczy sposób zmieniło dotychczasowy stan rzeczy. Tereny te pokryły się bowiem prowizorycznymi, nietrwałymi konstrukcjami, w których rozwijały się różne formy codziennej egzystencji nowych mieszkańców. Fotografie można więc rozpatrywać z punktu widzenia cennego świadectwa wchodzenia człowieka $\mathrm{w}$ relację $\mathrm{z}$ miejscem. $\mathrm{W}$ moim odczuciu, niezwykle trafnie, $\mathrm{w}$ istocie, ukazują one proces zagospodarowywania nowej przestrzeni i przekształcania jej $\mathrm{w}$ „,swoje miejsce” 33 .

Ze zdjęć ukazujących Paryż z początku XX wieku wyłania się czytelny przekaz zbudowany na opozycji wynikłej ze zderzenia centrum (któremu Atget nie poświęca miejsca w swej twórczości) i peryferii. Centrum, według artysty, symbolizuje modernizację i wygodę, natomiast przedmieścia (zone) - pracę. Wyznaczając w ten sposób miejską konfigurację, dołącza Atget do grona artystów, którym bliską metodą pracy okaże się styl dokumentalny.

32 G. Le Gall, La rue. Tłumaczenie autorki.

33 G. Le Gall, Les habitants. 
Wielu fotografów z lat dwudziestych XX wieku uzna go w tym względzie za prekursora nowoczesnej fotografii ${ }^{34}$.

Twórczość artysty, początkowo krytykowana i szokująca brakiem szacunku dla reguł kompozycji, z czasem zyskała coraz większe uznanie krytyki ${ }^{35}$. Wielu fotografów przed i po Atgecie fascynowało się pejzażem miejskim, chcąc go utrwalić i przybliżyć. W tym celu podejmowali próby uchwycenia przestrzeni, jej uporządkowania lub wytyczenia nowej topografii. Atgetowi ta sztuka wyjątkowo się udała.

Powyższe rozważania zaledwie zarysowują kilka aspektów z bogatej spuścizny artysty, który w pełni zasługuje na miano wyjątkowego. Wciąż zaskakuje on dzisiejszego odbiorcę swym oryginalnym stylem, przekazem i własną wizją miejskich przestrzeni. To dlatego, jak sądzę, do zdjęć Atgeta warto sięgać i powracać; ich analiza z pewnością dostarczy wielu inspirujących przemyśleń, i to zarówno znawcom historii francuskiej stolicy, jak i fotografii. Przede wszystkim jednak należałoby podkreślić niewątpliwą wartość tych zdjęć dla badaczy kultury i zachęcić tym samym do spojrzenia na nie z perspektywy dorobku współczesnej antropologii. Interpretacja dzieła Atgeta i jego wizji Paryża wpisuje się bowiem w nurt badań nad zapisem codzienności, skłaniając do podjęcia refleksji nad sposobami jej utrwalenia.

Dla historyka kultury, antropologa czy etnografa możliwe jest spojrzenie na fotografię od strony jej niezamierzonej „etnograficzności”; dokumentuje drobiazgi codzienności, ale jest też z jednej strony opowieścią o relacjach człowieka i świata - próbuje je odtwarzać, z drugiej - zapisuje emocje, nie tracąc mocy ich wywoływania ${ }^{36}$.

Atget jako fotograf - świadek i kronikarz przemijania dostarcza swymi pracami wiedzy na temat kulturowych przemian miasta i jego mieszkańców. Paryskie fotografie Atgeta zapisują oraz opisują pewną rzeczywistość i jako takie muszą podlegać złożonym interpretacjom. Jednocześnie utrwalają one "przeszły świat", przekazując pewne wyobrażenie artysty o świecie i ludziach żyjących w konkretnej rzeczywistości społeczno-kulturowej. Rze-

\footnotetext{
34 Tamże.

35 S. Sontag, O fotografii, s. 188. Atget wywarł istotny wpływ m.in. na twórczość Henri Cartier-Bressona (1908-2004).

36 M. Sztandara, Fotografia etnograficzna $i$ "etnograficzność” fotografii: studium z historii myśli etnologicznej i fotografii II pot. XIX i I poł. XX wieku, Opole 2006, s. 14.
} 
czywistość ta kreowana jest przez ludzi związanych konkretnymi miejscami i w nich znajduje swoje odbicie ${ }^{37}$.

Ostatnia refleksja dotyczy obrazu francuskiej stolicy, jaki wyłania się z Atgetowskich fotografii. Szczególnie cenny i interesujący wydaje mi się fakt, że ukazują one takie oblicze Paryża, do jakiego nie przywykliśmy. Stwierdzenie tego faktu wywołuje $\mathrm{w}$ nas pewną konsternację, a nawet zakłopotanie, gdyż podważa nasze kulturowe wyobrażenie przedstawianych przez niego miejsc. Obcowanie z fotografiami Atgeta niewątpliwie burzy powszechny i zazwyczaj schematyczny, stereotypowy sposób postrzegania Paryża. Może więc wizja tego miasta, wykreowana przez Atgeta, skłoni współczesnego odbiorcę do odkrywania jego „nieznanego" obrazu?

\section{Places and People in Photographs. Eugène Atget's Paris}

\section{Summary}

The article presents the person and output of the French photographer Eugène Atget (1857-1927). The artist was famous for his diligence in photographing the changes occurring in Paris as the result of a reconstruction originated during the Second Empire. The enormous legacy of the artist-documentalist (c. 10 thousand photos) shows perishing places in the capital of France as well as representatives of dying out trades. The author is especially interested in Atget's fascination with life on the peripheries of the metropolis.

37 Tamże, s. 8. Pisząc o interpretacji fotografii, autorka wylicza trzy poziomy: indywidualizujący, kulturowy i poznawczy. 